\title{
SHIFTS OF TRIGONOMETRIC POINTS IN THE AREA AFFECTED BY MINING ACTIVITIES \\ POSUNY TRIGONOMETRICKÝCH BODŮ NA ÚZEMÍ OVLIVNĚNÉM HORNICKOU ČINNOSTÍ
}

\author{
Marek MIKOLÁS̆ ${ }^{1}$, Milan MIKOLÁ $\check{S}^{2}$, Petra ZÁPALKOVÁ ${ }^{3}$ \\ ${ }^{1}$ Ing., Institute of Geodesy and Mine Surveying \\ Faculty of Mining and Geology, \\ VSB-Technical University of Ostrava, 17. listopadu 15, 70833 Ostrava - Poruba, Czech Republic \\ e-mail:marek.mikolas@vsb.cz \\ ${ }^{2}$ doc. Ing. Ph.D., Institute of Mining Engineering and Safety \\ Faculty of Mining and Geology, \\ VSB-Technical University of Ostrava, 17. listopadu 15, 70833 Ostrava - Poruba, Czech Republic \\ e-mail: milan.mikolas@vsb.cz \\ ${ }^{3}$ Ing., Institute of Geodesy and Mine Surveying \\ Faculty of Mining and Geology, \\ VSB-Technical University of Ostrava, 17. listopadu 15, 70833 Ostrava - Poruba, Czech Republic \\ e-mail:petra.zapalkova.st@vsb.cz
}

\begin{abstract}
In the underground mining of deposits, except the subsidence of layers also a horizontal shift occurs. The shift of trigonometric points is detected by the renewal of network. Formerly, the new triangulation of the overall area of interest has been carried out and since 1991 with the onset of modern observation techniques the GNSS technology has been used in full, which is not so time-consuming and economically demanding as triangulation works.
\end{abstract}

Abstrakt

Při hlubinném dobývání ložisek nastává nejen sedání vrstev, nýbrž i vodorovný posun. Tento posun trigonometrických bodů je zjištěn měřickou obnovou sítě. Dříve byla prováděna nová triangulace celého zájmového území a od roku $1991 \mathrm{~s}$ nástupem moderní observační techniky se využívá v plném rozsahu technologie GNSS, která není tak časově a ekonomicky náročná jako triangulační práce.

Keywords: influences of undermining, trigonometric points, triangulation, GNSS.

\section{INTRODUCTION}

After the extraction of part of a deposit, according to [8], an empty space occurs where right away, or after a certain time period the caving of rock fragments, or an elastic contact of the upper wall with the lower wall appears due to the concentrated stress in the surrounding rocks. This phenomenon may manifest up to the surface, where a subsidence trough appears.

A subsidence trough is, according to [2], part of the dish- or bell-shaped earth's surface, which originates due to the subsidence of overlying strata into the extracted space. Previous measurements of a number of authors showed that after extracting a horizontally stored seam deposit, a subsidence trough appears on the surface whose range is greater than the projection of the mined out area to the surface. The overlap over the projection of the extracted seam area is called the radius of influence, which is equal to the radius of effective area $r_{\tilde{u} \tilde{c}}$. The radius of the full effective area depends on the depth of the deposit $h$ and the boundary angle $\mu$, and is expressed by the following relation:

$$
r_{u \breve{c}}=h \cdot \operatorname{cotg} \mu
$$




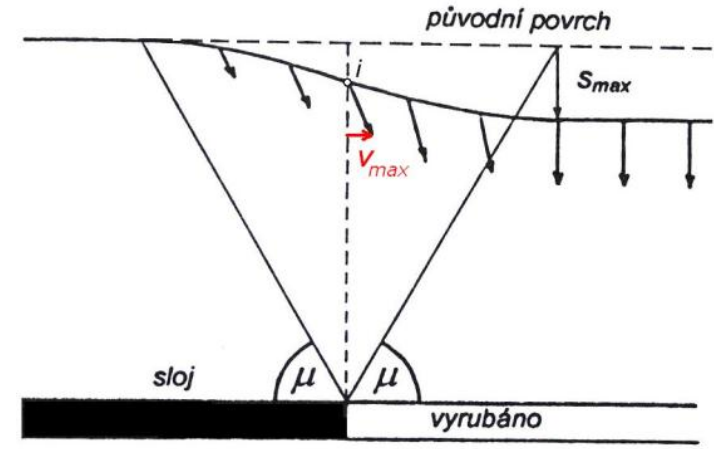

Fig. 1 Movements of points in a subsidence through [6]

For points on the slope of a subsidence trough not just a simple subsidence occurs, according to [6], but a general spatial motion (see Fig. 1). The overall motion of individual points can then be divided into the subsidence and horizontal shift. The course of horizontal shifts is generally expressed by a bell curve which shows that the largest shifts are over the edge of face. For points undermined by a full effective area, i.e. for $s_{\max }$, the horizontal shifts are equal to zero, just as at the edge of the subsidence trough. In more detail, the process of subsidence trough occurrence is described in [2], [6] and [8]. These motions in the subsidence trough have a negative impact on the quality of geodetic control.

\section{HORIZONTAL GEODETIC CONTROL IN CR}

The points of the Czech State Trigonometric Network, together with the reference points of zero-order network, astro-geodetic network and the points of geodynamic network forms the fundamental horizontal control.

Establishing the Czech State Trigonometric Network, formerly the Czechoslovak Uniform Trigonometric Network took place, according to [1], in the years 1920-1957 took place in three basic stages:

1. surveying the trigonometric network (1920-1927),

2. surveying and processing the trigonometric network of 1st order (1928-1937),

3. surveying and processing the trigonometric network of 2 nd to 5 th order (1928-1957).

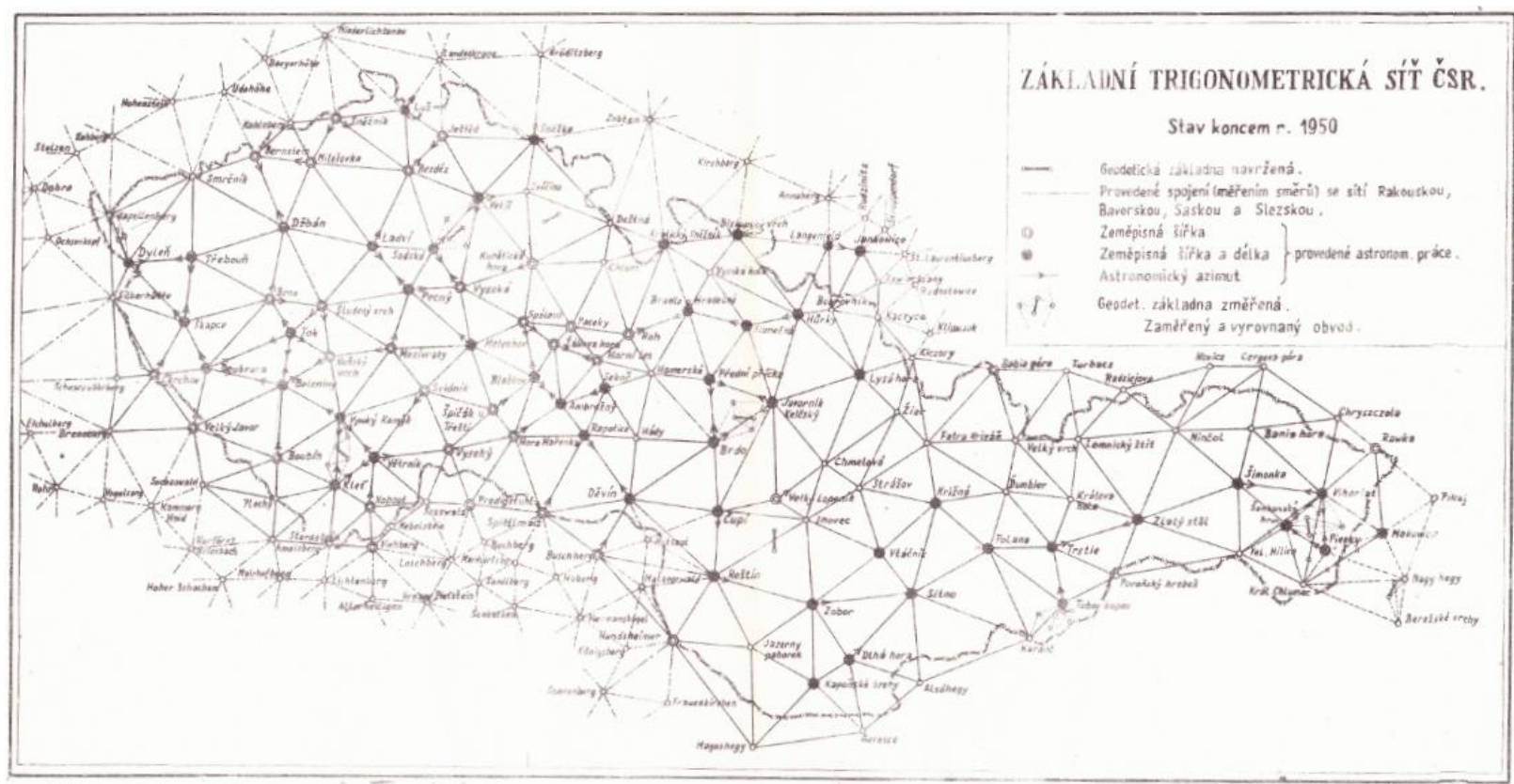

Fig. 2 Fundamental trigonometric network [9]

From the time or technical reasons:

- new astronomical measurements have not been performed,

- geodetic control has not been measured, 
- $\quad$ network was not connected with the neighboring countries.

At 42 points in the Czech Republic and 22 points in Ruthenia, according [10], the measured set of directions was taken from military triangulation. The network contained 237 points; the network adjustment was carried out according to the conditional measurements, where 559 normal equations were solved by successive approximation. The network in the Slovak Republic was connected to this network in 1926. It contained a total of 268 points and 456 triangles.

In the course of establishing, the advanced principle - from large to small - was followed. First, the fundamental trigonometric network was built and then the trigonometric networks of 1 st to 5th order were gradually inserted, until the average distance of points was suitable for establishing the horizontal control (1.5 - 2 $\mathrm{km})$.

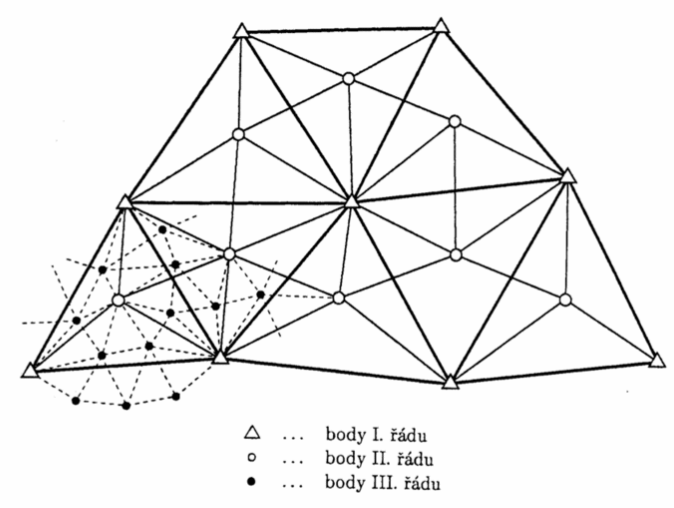

Fig. 3 Establishing horizontal controls [1]

As the basic element a triangle was chosen, which guarantees the best rigidity of the network and therefore the network is designated as a trigonometric (triangular) one.

\subsection{Stabilization of trigonometric points}

The location of the point of the fundamental horizontal control, according to [12], was chosen so that:

- it was not threatened,

- $\quad$ its signalization was simple,

- $\quad$ it was usable for the connection of points of horizontal control.

The trigonometric point is, according to [12], stabilized by marks in one of the following ways:

1. By a surface mark and two underground marks.

The surface mark is a stone prism (usually granite) with a machined head and a carved cross in the direction of the diagonals of the upper surface of the prism head. The top underground mark is a stone slab and the lower underground mark is a glass or stone slab, having crosses as surface marks. The centres of the crosses of all the marks, which the coordinates are related to, must be placed in a vertical with a limit tolerance of $3 \mathrm{~mm}$.

2. By a surface mark according to letter a) and an underground mark that is a stone slab with a cross as in case of the surface mark, concreted into the rock.

3. By a surface mark according to letter a) or a bench mark with a cross, or by a hole, being concreted in the rock (rock stabilization). In both cases, the mark of the trigonometric point is secured by four concreted bench marks with crosses or two witness points.

4. By a metal pin with a cross bedded into the flat roof of a building; this mark is secured by two witness points located outside the building,

5. By two cantilever marks embedded into the vertical surface of buildings. The point coordinates are relative to the top of an imaginary isosceles triangle (length of sides is $1.390 \mathrm{~m}$ ), whose base is defined by the cantilever marks. The altitude is always related to the upper surface of the left cantilever when viewed from the top of the triangle. The trigonometric point is secured by two witness points.

A permanently targeted trigonometric point (church tower finial, etc.) is always secured by two witness points. These points and the trigonometric point must be mutually visible. 
The first witness point is stabilized as a trigonometric point by three marks according to section 1). The second witness point is stabilized by surface and upper underground marks in accordance with section 1); the size of the surface mark is $160 \times 160 \times 750 \mathrm{~mm}$.

\subsection{Methods of establishing a trigonometric network}

To establish trigonometric networks [1] the following methods were used:

- triangulation

- trilateration

- combination of triangulation and trilateration

Triangulation

In the trigonometric network, all angles are measured in each triangle. The third angle is a redundant element that is used to review and adjust the network.

To determine the size of the network it is necessary to know the length of at least one datum trigonometric side. Previously, it was not possible to measure the length directly and therefore the so-called length base lines were measured and the lengths of all other sides were gradually derived by sine rules. In practice, however, several length bases were measured. This resulted in a more accurate network and avoided inaccuracies in the results caused by the accumulation of errors in angle measurements.

For the orientation of the network on an ellipsoid it is necessary to measure the azimuth of a side. If coordinates $\varphi$ and $\lambda$ (directly related to the Earth's surface) are determined astronomically for the datum point, the geographic coordinates $(\varphi, \lambda)$ of all other points can be calculated from the lengths of sides and their azimuths. The entire network is transferred from the ellipsoid to a suitably chosen display surface and the rectangular coordinates of the network are calculated in a selected coordinate system.

\section{Trilateration}

In trilateration, the lengths of all trigonometric sides in the network are measured. This solution was possible only with the onset of electronic rangefinders. The lengths can be adjusted either directly on the ellipsoid, or in the plane of a selected cartographic view. The location and orientation of the network on the ellipsoid are determined in the same way as in triangulation (astronomically by measuring coordinates and azimuths at least on the datum point).

\section{The combination of triangulation and trilateration}

In the network, all angles or some lengths, or vice versa, are measured, or all angles and all lengths. Such measurements are, of course, very costly and are conducted only in local networks.

\subsection{Modernization of geodetic control}

It was possible to proceed to establishing a modern geodetic control with the development of new technologies of observation techniques, utilizing in full observations of satellites of the GNSS technology. The year 1991 can be considered an initial period of establishing the geodetic control of a new type, when the realization of the concept - "The concept of modernization and development of the Czechoslovak geodetic control" approved in accordance with [1] in 1990 - was initiated.

The main characteristics of the modern geodetic control are as follows:

1. reducing the importance of a hierarchical structure of classical geodetic networks,

2. determining the horizontal and vertical position of points with using the methods of space geodesy,

3. homogeneity in the range of large territorial units,

4. universal use for solving scientific and practical problems of geodesy and surveying,

5. assignment of space-time characteristics to reference sets of points

6. integrated approach (including the clear assignment of physical parameters of the gravity control to geometrical parameters and clear defining the relationships between the position of the point in threedimensional geometric and gravity spaces,

7. flexibility of use. 


\subsubsection{Czech Positioning System "CZEPOS"}

CZEPOS provides users with the GNSS correction data for accurate positioning in the Czech Republic. CZEPOS is administered and operated by the Land Survey Office as part of the geodetic control of the Czech Republic.

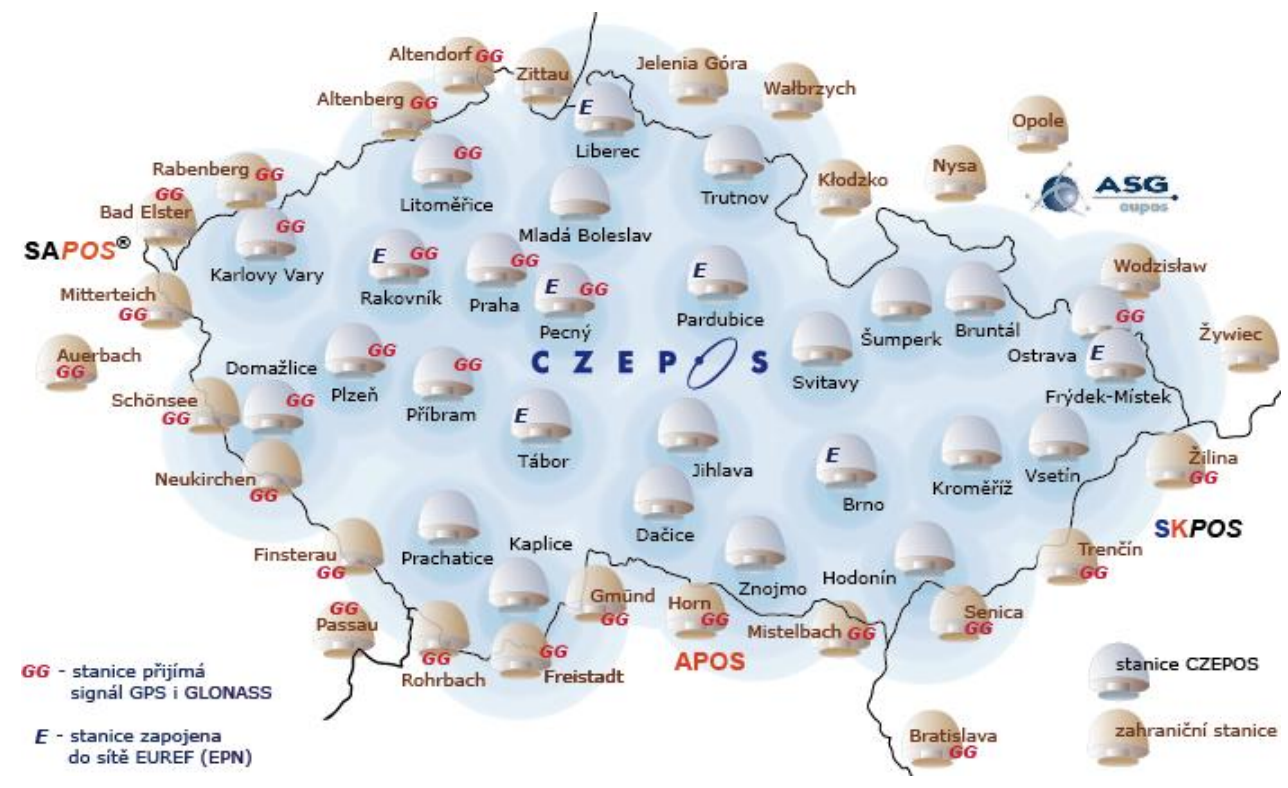

Fig. 4 Czech Positioning System [3]

CZEPOS, according to [3], contains 27 permanent stations with a spacing of $60 \mathrm{~km}$ in the territory of the Czech Republic. The total includes 27 stations located in the Czech Republic and 27 border stations of GNSS networks of neighbouring countries. In the Czech Republic there are 23 CZEPOS stations, which are administered by the Land Survey Office and are located on buildings of land registry offices, or workplaces and 4 external stations administered by the research and academic institutions.
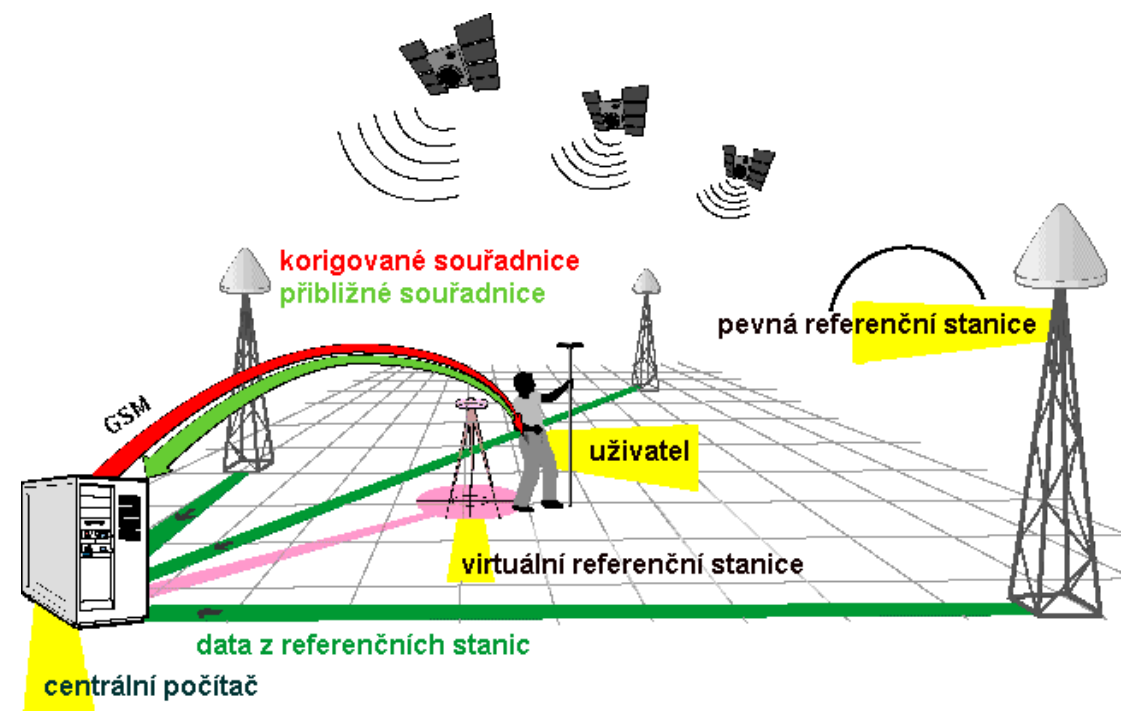

\footnotetext{
adjusted coordinates

approximate coordinates

permanent reference station user

virtual reference station

data from reference stations central computer
}

Fig. 5 The principle of measurements in the CZEPOS network [5] 


\section{EXISTING MONITORING OF TRIGONOMETRIC POINTS}

\subsection{Triangulation works by the year 1950}

In 1950, according to [7], the Ostrava-Karvina Coalfield was continuously newly triangulated in collaboration with surveying and mining experts. The new triangulation was carried out on the proposal of the headquarters of $\mathrm{OKD}$, the national enterprise, which needed the accurate data corresponding to reality for the elaboration of new details for planning. Under the previous regime, the area - now administered by this enterprise - was shared by several large and several smaller coal mines which performed surveying works almost always independently of each other. The public administration had its surveying requirements and triangulated for the needs of individual administrative sectors. Triangulation works were carried out in the Ostrava-Karvina Coalfield in the years 1924, 1929, 1932, 1935, 1944 and 1949.

An observation was performed on trigonometric points; the coordinates were re-adjusted, thus allowing comparing the results mutually. During these years, the experience with the motions of trigonometric points had been collected and used in the new triangulation in 1950.

\subsubsection{Principles of the new triangulation}

First, it was agreed, according to [7], to establish a new third-order network in the undermined area with the sides about $8 \mathrm{~km}$ long. The network was connected to the trigonometric points located a few kilometres from the border of mining, whose coordinates can be assumed not to be affected by its influence. Into the control created in such a way, 4th and 5th order and densification points were inserted.

Second, the location of trigonometric points in the new network was solved in relation to mining sites and thereby occurring motions of the surface. The areas in the immediate vicinity of mining pits, which are secured by a protective pillar, were recognized as the most suitable. According to the previous experience with triangulations these sites have good stability in both horizontal and vertical directions.

Third, it was agreed the survey markers of the trigonometric points located at the mining pits to be made solely by means of wooden survey signals and observation towers with a built-in table. Lightning conductors, flagpoles and other equipment of mining towers were not taken as the points with permanent beaconing due to their deflection and vibration during continuous mining operations. The stabilization of points at mining pits was always performed at ground level.

\subsubsection{Horizontal motions of trigonometric points due to undermining}

The network of $1950 \mathrm{had}$, according to [7], the same trigonometric points as the points identified in the previous triangulations. This circumstance allowed determining the size of the horizontal shift of trigonometric points. Due to the new adjustment of the points of the minor triangulation network, the change in coordinates usually does not exceed the value of $\pm 0.05 \mathrm{~m}$. For purposes of assessment of horizontal motions it was determined that the change in coordinates over the value of $0.05 \mathrm{~m}$ had been caused due to undermining.

The motions of trigonometric points identified in the network adjustment in 1950 are shown in Fig. 7. These motions can be compared with Fig. 6, containing the results of triangulations carried out in 1944. At the trigonometric points, lying in the northern part of the new triangulation, shifts towards the north are visible. It is caused by the fact that, according to [4], in 1944 the triangulation could not be properly developed as part of the undermined area was occupied. The triangulation had to be terminated on the trigonometric points lying still in undermined areas. The largest shift at a point stabilized in the ground was discovered at the trigonometric point "U Neumanskeho", which was $0.64 \mathrm{~m}$ in the SW direction. For naturally targeted points (towers of churches, chimneys and water plants) even larger shifts were found. An interesting example is the motion of the church in Vitkovice and in Hrusov, where in two time periods approximately the same direction of motion were preserved, whereas at the church in Michalkovice the direction was nearly opposite (see Fig. 6).

The horizontal shift at the church towers can be explained still in another way. Even a smaller soil subsidence on one side of the tower will cause the tilt and great shift of the finial in the horizontal direction.

It is evident from Fig. 7 that the trigonometric points lying at the edge of the undermined area tend to shift into its centre compared to Fig. 6 where the triangulation was completed at the points in the undermined area. 


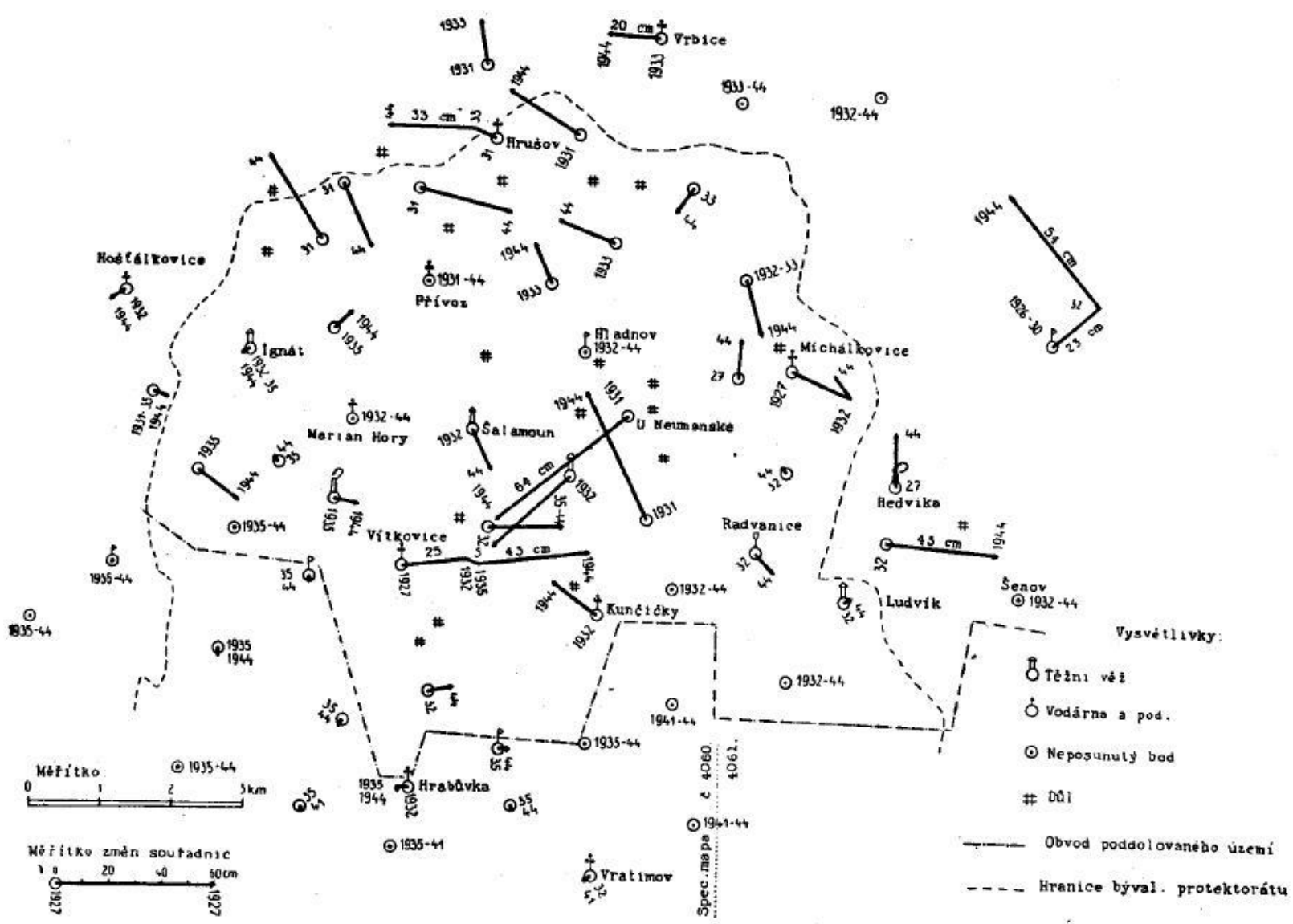

Fig. 6 Shifts of trigonometric points due to undermining by the year 1944 [4]

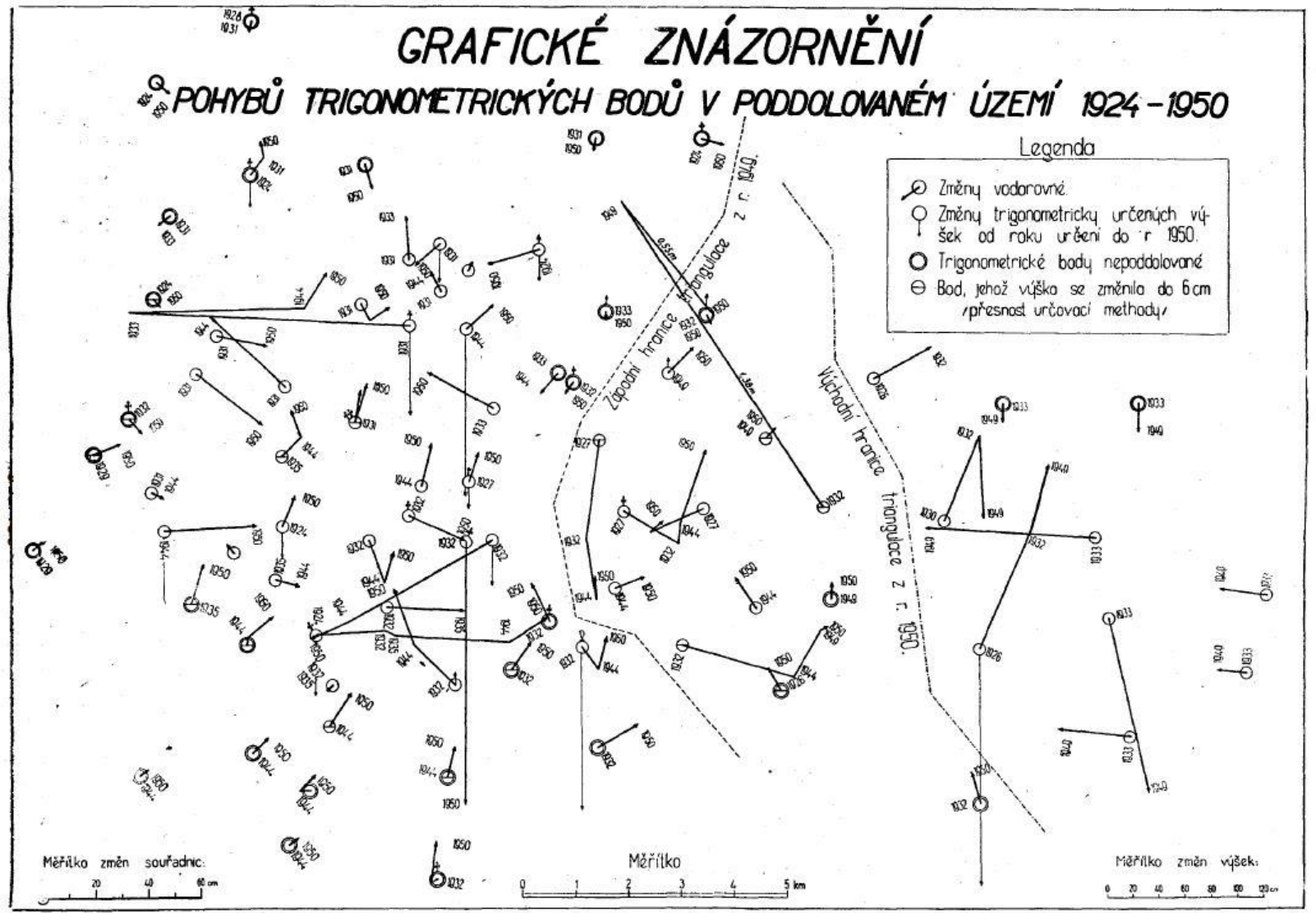

Fig. 7 Shifts of trigonometric points due to undermining by the year 1950 [7] 


\subsection{Triangulation works after 1950}

Further renewal of the trigonometric network was carried out at intervals of 5 to 7 years by the Land Survey Office.

For the analysis of horizontal deformations of the surface is in [11] used the renewal of the trigonometric network, which took place in the Ostrava-Karvina Coalfield in the years 1974-1980.

The input for the calculation of interpolated shifts and deformations is the data set containing the coordinates of trigonometric network points and the values of their shifts. To calculate the interpolated shifts 114 points were used (see Fig. 8).

The attempt to simplify the interpretation of the results shows the clearly identifiable areas, to which the interpolated shifts and hence also corresponding areas with high values of tension and compression deformations converge. The size of shifts (more than $0.5 \mathrm{~m}$ in the mentioned 6 years) and the corresponding deformations are really great and just this allows to determine these areas reliably. For better illustration, Fig. 9 shows a cut of one of those areas demonstrating the shifts at the points of the trigonometric network and deformations determined from them.

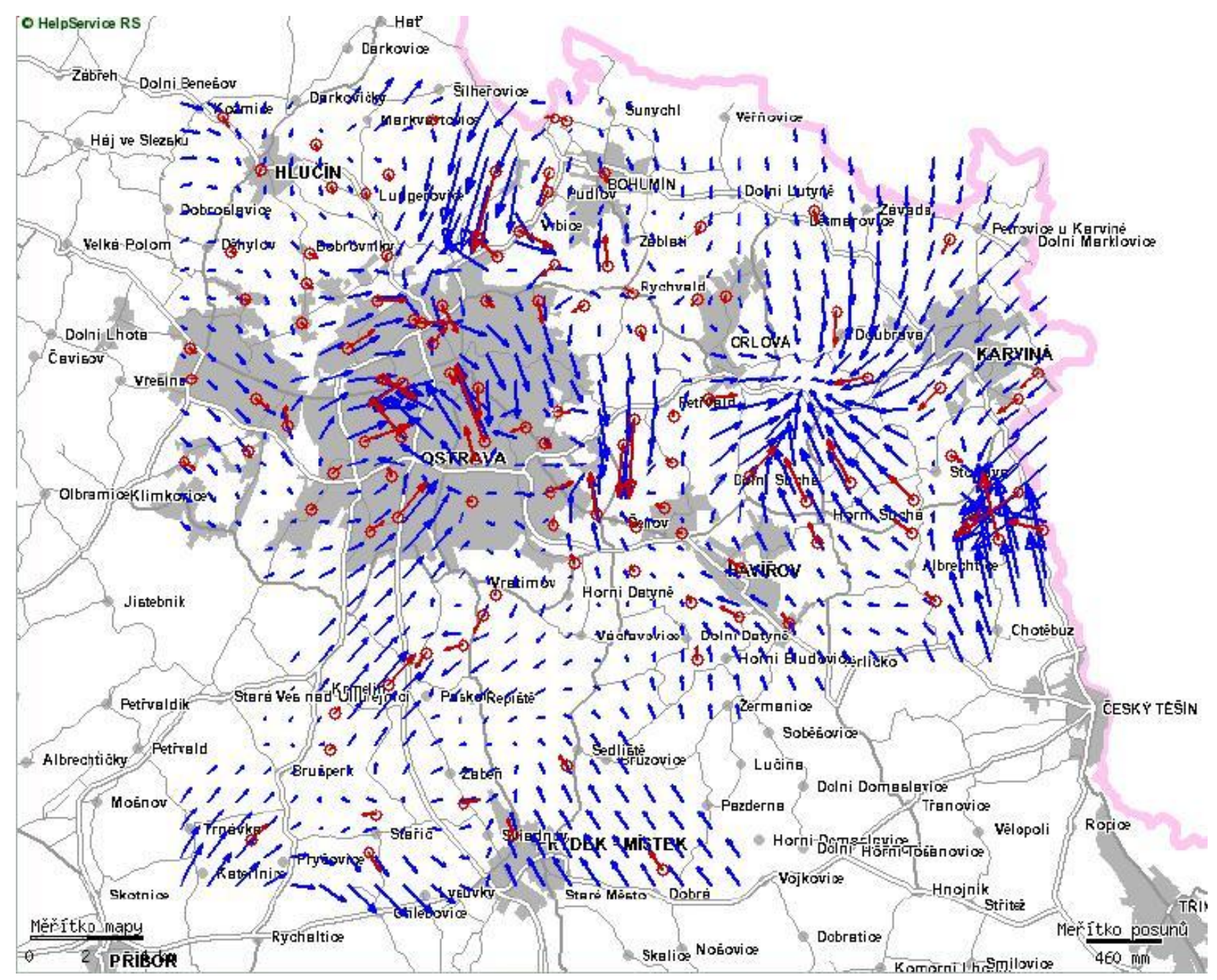

Fig. 8 Given and interpolated shifts for the Ostrava network in 1974-1980 [11] 


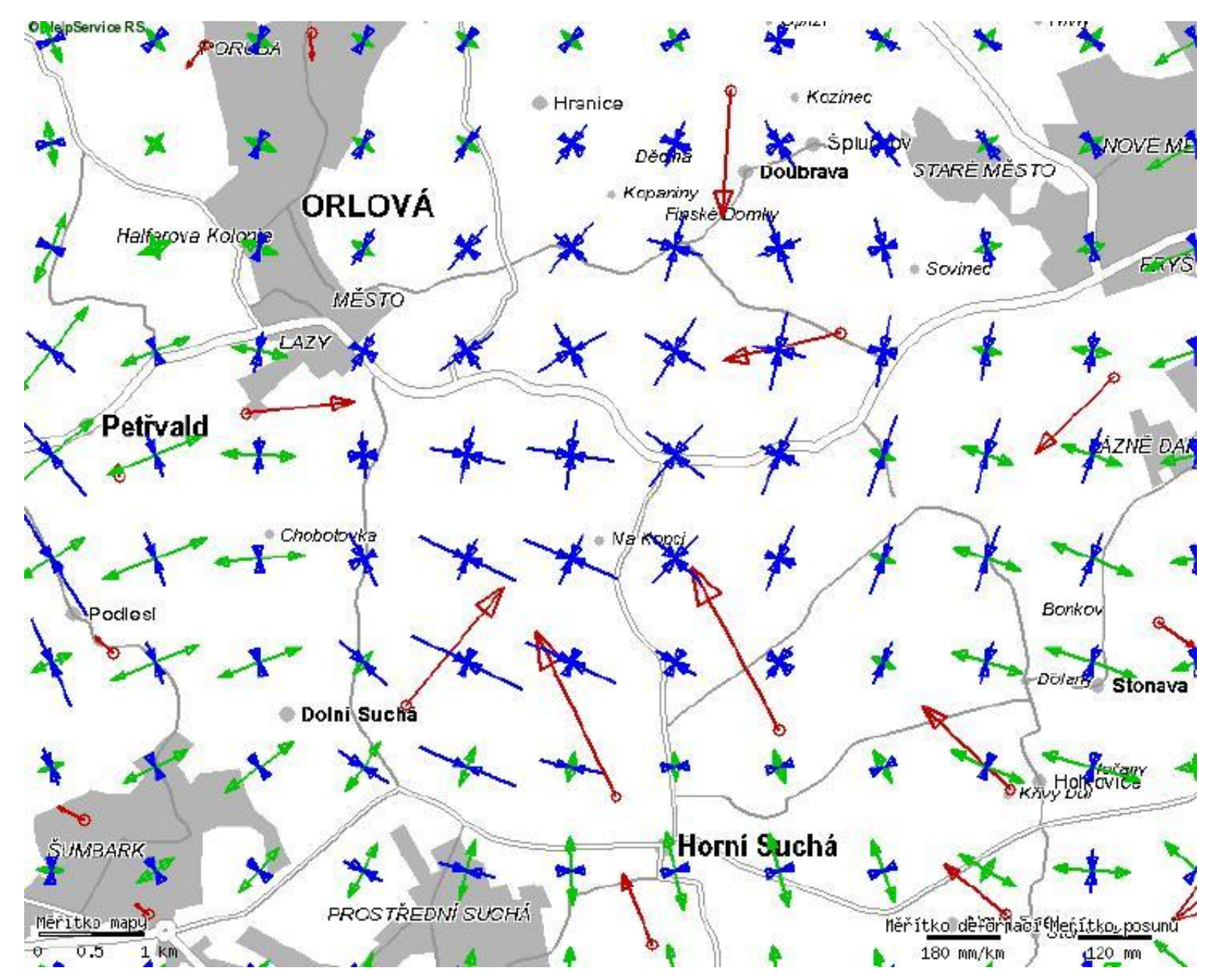

Fig. 9 Given shifts and determined deformations for the Ostrava network in 1974-1980 [11]

\section{CONCLUSIONS}

The issue of horizontal shifts of horizontal geodetic control is still a current topic. In the horizontal shifts of land, together with the trigonometric points also the points of minor horizontal control and landmarks moved, which were stabilized in the fracture points of property boundaries of lots.

Nowadays, we are more interested in Karvina part of the Ostrava-Karvina Coalfield, where there are three active mines (Karvina Mine, Darkov Mine, CSM Mine), compared to the southern part, where there is only one active mine (Paskov Mine).

The renewal of the trigonometric network is performed at intervals of five years. During this time, however, shifts of trigonometric points were observed for more than $0.5 \mathrm{~m}$. Therefore, we recommend connecting any surveying activity in the area affected by mining activities to the newly established points determined by the GNSS technology.

\section{REFERENCES}

[1] CIMBÁLNÍK, M. - MERVART, L.: Vyšší geodézie 1. Skriptum ČVUT, Praha 2002

[2] ČECHURA, F. - NESET, K.: Kurs důlního měřictví. SNTL, Praha 1956

[3] Česká sit’ permanentních stanic pro určování polohy “CZEPOS“" [cit. 2011-10-10] Dostupné na WWW: <http://czepos.cuzk.cz>

[4] FORMAN, V.: Pohyby trigonometrických bobů způsobené poddolováním. Zeměměřický obzor 7/34, 1946, č. 9-10, str. 151-153

[5] KOPAL, A. - PETR, R.: Bude celoplošná sit’ referenčních stanic DGPS v ČR a SR? Zeměměřič, 1999, č. 12, [cit. 2011-10-10] Dostupné na WWW: <http://www.zememeric.cz>

[6] KOVANIČ, L. - MATOUŠ, J. - MUČKA, A.: Důlní měřictví. SNTL, Praha 1990

[7] MENŠÍK, V.: Triangulace v poddolovaném území. Zeměměřictví 2/40, 1952, č. 12, str. 181-185 
[8] NESET, K.: Vlivy poddolování. SNTL, Praha 1984

[9] RYŠAVÝ, J.: Vyšší geodesie. ČMT, Praha 1947

[10] STAŇKOVÁ, H.: Vznik a vývoj souradnicových systémů SK, JTSK a ETRS89 na území Moravy a Slezska. Geodetický a kartografický obzor 53/95, 2007, č. 10, str. 233-245

[11] TALICH, M.: Analýza deformaci v poddolovaných lokalitách z opakovaných polohových měrení s využitím webové aplikace a mapových služeb WMS. Acta Montanistica Slovaca. 12, 2007, č. 3, str. $567-$ 575, [cit. 2011-10-10] Dostupné na WWW: < http://www.vugtk.cz/ deformace >

[12] Vyhláška ČÚZK č. 31/1995 Sb., kterou se provádí zákon č. 200/1994 Sb., o zeměměřictví a o změně a doplnění některých zákonů souvisejících s jeho zavedením, ve znění vyhlášky č. 212/1995 Sb., vyhlášky č. 365/2001 Sb., vyhlášky č. 92/2005 Sb. a vyhlášky č. 311/2009 Sb.

\section{RESUMÉ}

Příspěvek se zabývá posuny trigonometrických bodů na území ovlivněném hornickou činností. V první části je popsán vliv hlubinného dobývání na povrch a stručný vývoj polohových geodetických základů ČR. Dále jsou $\mathrm{v}$ prř́spěvku shrnuty zkušenosti pracovníků, kteří prováděli triangulační práce v Ostravsko-karvinském revíru v letech 1944, 1949 a 1950 a grafická interpretace jejich výsledků. Na základě měřické obnovy trigonometrické sítě v letech 1974-1980 je zobrazena analýza deformací povrchu ve čtvercové síti.

The publication is part of the grant project SGS SP2011/8 "Reserch of accuracy of the fundamental control in the area affected by mining activities for subsequent geodetic survey". 